\title{
APPLICATION OF GEOPHYSICAL TECHNIQUES TO MINERALS-RELATED ENVIRONMENTAL PROBLEMS
}

By Ken Watson, David Fitterman, R.W. Saltus, Anne McCafferty, Gregg Swayze, Stan Church, Kathy Smith, Marty Goldhaber, Stan Robson, and Pete McMahon

Open-File Report 01-458

2001

This report is preliminary and had not been reviewed for conformity with U.S.

Geological Survey editorial standards or with the North American Stratigraphic Code. Any trade, firm, or product names is for descriptive purposes only and does not imply endorsement by the U.S. Government. 


\section{Contents}

1 Executive Summary 3

1.1 Application of methods . . . . . . . . . . . . . . . . 3

1.2 Mineral-environmental problems . . . . . . . . . . . . . 3

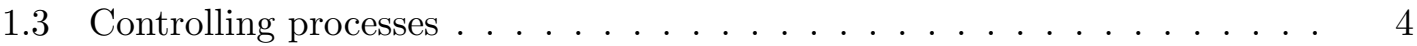

1.4 Geophysical techniques . . . . . . . . . . . . . . . . . . 5

1.4.1 Electrical and electromagnetic methods ........... 5

1.4 .2 Seismic methods . . . . . . . . . . . . . . . 6

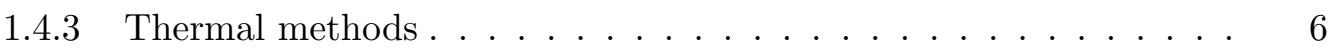

1.4.4 Remote sensing methods . . . . . . . . . . . . . . . 6

1.4.5 Potential field methods . . . . . . . . . . . . . . 7

1.4.6 Other geophysical methods . . . . . . . . . . . . . . 7

$\begin{array}{llr}2 & \text { Introduction } & 8\end{array}$

3 Mineral-environmental Applications of Geophysics $\quad 10$

4 Mineral-environmental Problems $\quad 13$

4.1 The sources of potentially harmful substances . . . . . . . . . . . . . 15

4.2 Mobility of potentially harmful substances . . . . . . . . . . . . 15

4.3 Transport of potentially harmful substances . . . . . . . . . . . . . 16

4.4 Pathways for transport of potentially harmful substances . . . . . . . . . 17

4.5 Interaction of potentially harmful substances with the environment . . . . 18

5 Processes Controlling Mineral-Environmental Problems 18

5.1 Geochemical processes . . . . . . . . . . . . . . . . . . 19

5.1.1 Chemical Weathering (near-surface reactions) . . . . . . . . 19

5.1 .2 Deep alteration $($ reactions at depth) . . . . . . . . . . 20

5.1 .3 Microbial catalysis . . . . . . . . . . . . . . . 21

5.2 Fluid flow . . . . . . . . . . . . . . . . . . . 21

5.3 Biologic/geologic interactions . . . . . . . . . . . . . . 22

5.4 Energy flow . . . . . . . . . . . . . . . . . 23

5.5 Mass movement . . . . . . . . . . . . . . . . . 23

6 Description of Geophysical Techniques 25

6.1 Electrical and electromagnetic methods . . . . . . . . . . . . 26

6.2 Seismic methods . . . . . . . . . . . . . . . . . 28

6.3 Thermal methods . . . . . . . . . . . . . . . . . . . . 29

6.4 Remote sensing methods . . . . . . . . . . . . . . . . . . . . . . . . . . . . . . . . .

6.5 Potential fields methods . . . . . . . . . . . . . . . . . . 33

6.6 Other geophysical methods . . . . . . . . . . . . . . 35

7 Glossary of Terms $\quad 36$

8 References $\quad 40$ 


\section{List of Tables}

1 Mineral-environmental applications of geophysical techniques . . . . . . . 10

2 Potentially harmful substances related to mineral concentrations and mining 14 


\section{Executive Summary}

Geophysical techniques have many important applications to mineral-environmental problems. This report, the result of a collaborative effort by a team of geophysicists, geologists, geochemists and hydrologists, focuses on these issues: (1) characterizing environmental impacts associated with ore bodies, mining, and extraction, (2) the primary physical processes affecting these environmental impacts, and (3) the capabilities and limitations of geophysical methods with applications to these problems. A glossary of terms used in the report is included in Section 7.

\subsection{Application of methods}

Example applications of geophysical techniques to mineral-environmental problems are summarized in Table 1 (Section 3), which lists application, problems, processes, and geophysical methods and contains references to the appropriate sections of the report for details.

\subsection{Mineral-environmental problems}

We subdivide a typical mineral-environmental problem and discuss the sources, mobility conditions, transport processes, pathways, and ultimate fate of potentially harmful substances. Geophysical techniques have important applications in all five areas. Concentration of potentially harmful substances can result from natural processes (such as formation of a metallic sulfide mineral deposit) or from anthropogenic activities (such as mining). A major factor in the mobilization of potentially harmful substances is contact with water and thus important parameters are those relating to surface and subsurface hydrologic flow. Dispersal as airborne particulates is a secondary process that depends on weather and local topography. Once the potentially harmful substances are mobilized, transport can occur by a variety of agents: water, wind, gravity, and the biota. 
Understanding the movement of water requires knowledge of hydrological pathways and processes. Surface flow is commonly localized by existing rivers and streams; the size of the channels, depth of fill, and bottom surface conditions are all factors that influence flow and are also functions of total and peak discharge for a drainage system. Other forms of surface flow include sheet runoff caused by cloudbursts or rapid melting of snow and ice pack. Subsurface flow, which is controlled by permeability and hydraulic head, depends on many factors including porosity, grain size, sorting, cementation, fractures, and connectivity of pore space. The zones of mixing between surface and subsurface flows may be critical to the understanding of contaminant flow. The fate of substances that are of most critical concern to humans depends on several processes: chemical changes of the substance over time which increase or decrease toxicity (such as natural cyanide breakdown and oxydation/reduction reactions), chemical reactivity of a substance (such as acid neutralization by a carbonate buffers), inappropriate use of potentially harmful materials (such as using mine tailings for road base), selective absorption by plants, grazing by livestock, uptake by biota, and aquifer contamination.

\subsection{Controlling processes}

Processes controlling mineral-environmental problems are divided into five categories: geochemical, fluid flow, biologic/geologic, energy flow, and mass movement. Geochemical reactions are subdivided into chemical weathering and deep alteration. Chemical reactions of weathering range from slow to rapid and may be incomplete or complete, but are commonly slow and incomplete. Stable end products include quartz, limonite, and kaolinite (Krauskopf, 1979). Oxidation reactions involving many sulfide minerals can produce acidic waters. Neutralization of these waters can be provided by the presence of many types of carbonate-bearing rocks. Alteration associated with the interaction of geothermal waters with surface waters can concentrate potentially harmful substances. Fluid 
flow is the most significant process contributing to environmental problems because it provides the medium for the reaction and the mechanism for transport. Both the surface and subsurface groundwater flows need to be understood in relationship to the geologic controls and interaction with the mineral deposit and mine-waste materials. Mapping permeability is an important aspect of modeling subsurface flow; geophysical methods can be used to complement and extend borehole data. Vegetation can have a profound effect on the dispersal and concentration of toxic substances by uptake, leaching, and re-deposition. Two examples of the importance of energy flow are the effects associated with underground coal fires and the heat generated by sulfide oxidation in mine waste piles. Mass movement can be a significant process because it can expose fresh material to weathering, transport hazardous material, or increase the subsurface permeability.

\subsection{Geophysical techniques}

Geophysical techniques are classified into the following groups: electrical, seismic, thermal, remote sensing, and potential fields. Their use can be restricted in some environmental studies depending on how invasive they are; satellite and aircraft data are the least invasive and borehole methods are the most.

\subsubsection{Electrical and electromagnetic methods}

Electrical and electromagnetic methods can be used to map subsurface variability in electrical properties caused by changes in lithology, structure, alteration, and contamination due to mining activity. These methods are sensitive to low resistivity targets and thus can be used to map the location and migration of drainage waters and mine-waste. The depth of investigation can range from less than a meter in the case of ground penetrating radar to tens and hundreds of meters for most other methods. Resolution of targets and detectability tend to decrease with increasing depth of burial. The induced polarization method can differentiate between various metallic sulfide and alteration minerals 
and holds promise as a means of characterizing mine-waste deposits. The self-potential method may be useful in studying waste piles because it responds to the presence of electrochemical cells and water flow in the ground.

\subsubsection{Seismic methods}

Seismic methods are sensitive to variations in the elastic properties and density of the subsurface and can be used to map important geologic, hydrologic, and physical interfaces including the base of a surficial weathering layer, the water table, stratigraphic or structural breaks between contrasting rock units and fractures. Typically, these methods are most effective in regions with sub-horizontally-layered subsurface interfaces.

\subsubsection{Thermal methods}

Thermal methods, which use probes to measure subsurface temperature, have potential for monitoring exothermic or endothermic geochemical reactions in mine tailings and waste ponds, and application to three-dimensional models of fluid flow.

\subsubsection{Remote sensing methods}

Thematic Mapper (TM) satellite data have been be used to map surface alteration at 30m ground resolution and new satellite systems will be launched shortly with spatial resolution capable of detecting features as small as tailings piles. Improved spectral resolution of satellite data will make it possible to detect individual minerals for more detailed analysis. Aircraft data is now used to map alteration zonation, lithologic differences, surface temperature, and vegetation type and state. In particular, imaging spectroscopy is used for mapping a wide variety of minerals (iron-bearing minerals, phyllosilicates, carbonates, sulfates) as well as vegetation species and stress, and has been shown to be a powerful tool for mapping ground alteration and detecting lithologies that can act as acid-neutralizing agents. Multispectral thermal scanners can be used to map igneous lithologies, and silicic 
alteration, and may have potential use for detecting heating or cooling caused by chemical reactions in waste piles. Limitations of remote sensing include masking of surface mineralogy/lithology where extensive vegetation cover is present, residual solar/topographic heating effects in areas of moderate to high relief, and high sensitivity to surface weathering.

\subsubsection{Potential field methods}

Gravity and magnetic methods can yield important three-dimensional geologic information. Gravity data, for example, can be used to model the shape of a basin containing young sedimentary rocks juxtaposed against higher density basement rocks. Magnetic data can provide complementary information if there is a magnetic contrast between the sedimentary rocks and the basement. Mapping the sediment/basement interface can be important for understanding movement of subsurface water. Faults may often be traced by mapping offsets of both gravity and magnetic source bodies. Magnetic data can also be useful for finding abandoned wells and buried drums, and locating and mapping waste dumps. High-resolution repeat gravity measurements may be useful to track changes in the water table or movement of unstable slopes.

\subsubsection{Other geophysical methods}

Other geophysical methods with application to mineral-environmental problems include microwave (active and passive), borehole logging, GPS methods, rock property laboratory measurements, and radiometrics. Microwave methods have a ground penetration of up to several meters and can be used to examine near surface heating and for detecting shallow dielectric property changes related to dry versus wet or frozen versus unfrozen ground. Borehole logging includes virtually all geophysical methods that can be conducted on the ground and provide detailed measurements for determining physical properties in a depth profile. GPS methods can be used to track very small Earth movements between 
stations to measure subtle ground movements which might be precursors of landslides or other hazardous ground movement. Laboratory measurements refers to the empirical characterization of physical rock properties such as porosity and permeability and their relationship to other physical properties that are directly measured. Radiometrics includes the use of airborne surveys to estimate abundances of potassium, thorium, and uranium for a variety of activities including regional lithologic discrimination, mineral exploration, and environmental background studies.

\section{Introduction}

The U. S. Geological Survey (USGS) formed an interdisciplinary team in late 1995 to examine the role of geophysics in mineral-environmental studies of the USGS Mineral Resource Program. The team discussions examined USGS technical capabilities, defined their relevance to mineral-environmental studies with focus on applications, and addressed such critical issues as interdisciplinary needs, development of new techniques, database management, and connections to other Geologic Division programs and to cooperative activities. The overall objective of the task was production of this report. The interdisciplinary composition of the group insured that the report, which resulted from discussions between geophysicists, geologists, geochemists and hydrologists, would address real problems using the best understanding of the capabilities of the methods. A team approach was used to identify key issues in our understanding of processes affecting environmental impacts of mineral concentrations and minerals development, as well as hazards associated with previous mining. A by-product of these discussions was an increased awareness within the team of both the capabilities and limitations of geophysical methods and the types of problems that need to be addressed.

This report is intended to provide geophysicists with a background on the problems and processes that can be important for mineral- environmental problems and to acquaint 
geologists and geochemists with the substantial array of powerful geophysical techniques that can be brought to bear in the study of these problems. There are a great wealth of texts available on both environmental geochemistry and exploration geophysics but they are designed for specialists. It is the aim of this report to reach across the discipline boundaries. The difficulty is elegantly stated in a recent issue of Physics Today ( Herschbach, 1997): "The typical chemist wants above all to understand why one substance behaves differently from another; the physicist usually wants to find principles that transcend any specific substances." With that cultural background in mind geochemists and geophysicists face a real challenge as they plan to work together to solve the important mineral-environmental problems that we face.

The most comprehensive study to date of the application of geophysical methods to minerals-related environmental problems is a Canadian study which focused on the detection and monitoring of acid mine drainage (Paterson and others, 1994). The study emphasized the effectiveness of geophysics in recognizing and mapping the movement of acid effluents in and around mine workings from a variety of measurement platforms, ranging from satellites and aircraft to ground and waterborne. Patterson and others (1994) also stressed the importance of expanding the range of geophysical methods and applications into a greater variety of geologic and topographic settings. They also noted, as a common theme in the reviewed literature, the importance of integrating geophysical methods to resolve ambiguities and improve identification. A review of the applicability of geophysical methods to geoenvironmental studies of ore deposits (Hoover and others, 1995) provides a useful summary of methods with a discussion of how they should be applied for specific geoenvironmental investigations. 


\section{Mineral-environmental Applications of Geophysics}

This section summarizes, in a tabular form, some example applications of geophysical methods to mineral-environmental problems. The applications are listed alphabetically within groups, ordered by our subdivision of a typical mineral-environmental problem (see Section 4), as indicated by the references to subsequent sections in the Problems column. The Processes column provides references to subsections of our discussion of physical, chemical, and biological processes of importance to mineral-environmental problems. Finally, in the Geophysical methods column we list specific geophysical techniques with reference to the general technique discussions in Section 6. Brief definitions of many of the geophysical methods listed are also given in the glossary (Section 7).

Table 1: Mineral-environmental Applications of Geophysical Techniques. [Numbers in parentheses are references to subsequent sections of this report. Abbreviations and acronyms are defined in the glossary (Section 7).]

\begin{tabular}{|c|c|c|c|}
\hline Application & Problems $(4)$ & Processes $(5$ & Geophysical methods (6) \\
\hline $\begin{array}{l}\text { Alteration/weathering } \\
\text { mapping }\end{array}$ & Sources (4.1) & $\begin{array}{l}\text { Geochemical } \\
(5.1)\end{array}$ & $\begin{array}{l}\text { Most electrical methods }(6.1) \\
\text { Imaging spectroscopy }(6.4) \\
\text { Magnetics }(6.5) \\
\text { Spectral thermal }(6.4)\end{array}$ \\
\hline Geologic/lithologic mapping & Sources $(4.1)$ & All (5) & $\begin{array}{l}\text { Multispectral reflectance and } \\
\text { emission }(6.4) \\
\text { Imaging spectroscopy }(6.4) \\
\text { Radiometrics }(6.6) \\
\text { Most electrical methods }(6.1) \\
\text { Gravity and magnetic prop- } \\
\text { erty mapping }(6.5)\end{array}$ \\
\hline $3 \mathrm{D}$ ore deposit mapping & Sources $(4.1)$ & $\begin{array}{l}\text { Geochemical } \\
(5.1)\end{array}$ & $\begin{array}{l}\text { Most electrical methods }(6.1) \\
\text { Gravity and magnetics }(6.5)\end{array}$ \\
\hline
\end{tabular}


$3 \mathrm{D}$ waste pile mapping

Sources (4.1) Geochemical

Ground-based EM (6.1)

DC resistivity (6.1)

Induced Polarization (6.1)

Magnetics (6.5)

Self-potential, EM (6.1)

Shallow seismic surveys (6.2)

Ground-penetrating radar (6.1)

\begin{tabular}{|c|c|c|c|}
\hline Clay content mapping & Mobility (4.2) & $\begin{array}{l}\text { Geochemical } \\
(5.1)\end{array}$ & $\begin{array}{l}\text { Most EM methods }(6.1) \\
\text { Induced polarization }(6.1) \\
\text { Imaging spectroscopy }(6.4)\end{array}$ \\
\hline $\begin{array}{l}\text { Climate evaluation and } \\
\text { monitoring }\end{array}$ & $\begin{array}{l}\text { Mobility }(4.2) \\
\text { Transport } \\
(4.3)\end{array}$ & $\begin{array}{l}\text { Geochemical } \\
(5.1) \\
\text { Fluid flow }(5.2)\end{array}$ & $\begin{array}{l}\text { Multispectral reflectance and } \\
\text { emission }(6.4) \\
\text { Microwave (active and passive; } \\
6.6) \\
\text { Borehole thermometry }(6.3)\end{array}$ \\
\hline $\begin{array}{l}\text { Erosion mapping (near- } \\
\text { surface and sub-aqueous) }\end{array}$ & Mobility (4.2) & $\begin{array}{l}\text { Geochemical } \\
(5.1)\end{array}$ & $\begin{array}{l}\text { Aerial photography }(6.4) \\
\text { Thermal infrared }(6.4) \\
\text { Many EM methods }(6.1) \\
\text { Shallow seismic }(6.2)\end{array}$ \\
\hline Moisture content mapping & Mobility (4.2) & $\begin{array}{l}\text { Geochemical } \\
(5.1)\end{array}$ & $\begin{array}{l}\text { Thermal infrared (6.4) } \\
\text { Radar (airborne and ground) } \\
(6.4) \\
\text { Borehole logging }(6.6) \\
\text { Time-domain reflectrometry (TDR) } \\
(6.6)\end{array}$ \\
\hline $\begin{array}{l}\text { Ponding and seepage } \\
\text { mapping }\end{array}$ & Mobility (4.2) & $\begin{array}{l}\text { Geochemical } \\
(5.1) \\
\text { Fluid flow }(5.2)\end{array}$ & $\begin{array}{l}\text { Aerial photography }(6.4) \\
\text { Thermal infrared }(6.4) \\
\text { Many EM methods }(6.1) \\
\text { Shallow seismic }(6.2)\end{array}$ \\
\hline Slope stability measurement & Mobility (4.2) & Mass flow (5.5) & $\begin{array}{l}\text { Repeat gravity }(6.5) \\
\text { GPS repeat surveying }(6.6) \\
\text { Magnetic tracking of buried } \\
\text { magnets }(6.5) \\
\text { EM mapping of weak clay } \\
\text { zones }(6.1) \\
\text { Remote sensing }(6.4)\end{array}$ \\
\hline
\end{tabular}




\begin{tabular}{llll}
\hline Water table mapping & Mobility (4.2) & Geochemical & Ground-penetrating radar (1- \\
and monitoring & Transport & $(5.1)$ & 5 meters depth, 6.1) \\
& $(4.3)$ & Fluid flow (5.2) & DC resistivity (6.1) \\
& & SP (6.1) \\
& & Borehole logging (6.6) \\
& Gravity and magnetic base- \\
& ment mapping (6.5)
\end{tabular}

\begin{tabular}{llrl}
\hline Permeability and porosity & Transport & Fluid flow (5.2) & Borehole logging (6.6) \\
determination & $(4.3)$ & Laboratory measurements \\
& Pathways (4.4) & $(6.6)$ &
\end{tabular}

\begin{tabular}{|c|c|c|c|}
\hline $\begin{array}{l}\text { Subsurface water flow } \\
\text { rate measurement }\end{array}$ & $\begin{array}{l}\text { Transport } \\
(4.3)\end{array}$ & Fluid flow (5.2) & $\begin{array}{l}\text { Self-potential method (quali- } \\
\text { tative) }(6.1)\end{array}$ \\
\hline Surface flow modeling & $\begin{array}{l}\text { Transport } \\
(4.3) \\
\text { Pathways (4.4) }\end{array}$ & Fluid flow (5.2) & GIS modeling \\
\hline Fracture mapping & Pathways (4.4) & Fluid flow (5.2) & $\begin{array}{l}\text { VLF EM (6.1) } \\
\text { Self-potential EM }(6.1) \\
\text { Seismic tomography }(6.2) \\
\text { Radar tomography }(6.1) \\
\text { Gravity and magnetics }(6.5) \\
\text { Thermal infrared(6.4) }\end{array}$ \\
\hline Subsurface plume mapping & Pathways (4.4) & Fluid flow (5.2) & $\begin{array}{l}\text { Repeat borehole logging }(6.6) \\
\text { Many electrical and EM meth- } \\
\text { ods ( } 6.1) \\
\text { Ground-penetrating radar } \\
(6.1)\end{array}$ \\
\hline $\begin{array}{l}\text { Habitat mapping and } \\
\text { monitoring }\end{array}$ & Fate $(4.5)$ & Biological (5.3) & $\begin{array}{l}\text { Imaging spectroscopy }(6.4) \\
\text { Multispectral reflectance }(6.4) \\
\text { Thermal infrared }(6.4) \\
\text { SLAR }(6.4)\end{array}$ \\
\hline $\begin{array}{l}\text { Vegetation mapping and } \\
\text { monitoring }\end{array}$ & Fate $(4.5)$ & Biological (5.3) & $\begin{array}{l}\text { Imaging spectroscopy }(6.4) \\
\text { Multispectral reflectance }(6.4) \\
\text { Thermal infrared }(6.4)\end{array}$ \\
\hline
\end{tabular}




\section{Mineral-environmental Problems}

Minerals-related geoenvironmental problems are primarily concerned with the movement of potentially harmful substances (Table 2) from areas of mineral concentration as a result of both natural and anthropogenic processes. Characterization and understanding of these problems requires knowledge of:

1. Sources of potentially harmful substances,

2. Conditions under which the substances become mobile,

3. Processes that transport the substances,

4. Pathways available to these transport processes, and

5. Ultimate fates of these substances in the environment.

Geophysical methods can play an important role in studying each of these five areas (see examples listed in Table 1).

To illustrate this subdivision of a typical geoenvironmental problem, consider acid rock drainage. This problem is concerned not just with the transport of the acidic waters themselves, but with the capacity of these waters to carry metals. The exact nature of the leachates varies with the mineralogy of the source rocks and the composition of the leaching fluid. The degree to which metals are mobilized is influenced by the acidity and composition of the leaching fluid. Fluid flow is the typical transport process. The fluid flow pathways can include a variety of surface and subsurface paths. The ultimate fate of the metals in the environment can vary from precipitation in a geochemically stable form, to temporary deposition (in a river bottom, for example, at risk of further mobilization), to entry into the biosphere and atmosphere (plant and/or animal uptake). 
Table 2: Potentially harmful substances related to mineral concentrations and mining. [L, low mobility; M, moderate mobility; H, high mobility; N, relatively immobile]

\begin{tabular}{|c|c|c|c|c|}
\hline \multirow[t]{3}{*}{ Category } & \multirow[t]{3}{*}{ Substance } & \multicolumn{3}{|c|}{ Conditional Mobility* $^{*}$} \\
\hline & & Oxidizing & Oxidizing & Reducing \\
\hline & & $($ Acidic,$p H<3)$ & $\begin{array}{l}(p H>4) \\
\text { (with abundant } \\
\text { iron-rich } \\
\text { particulates) }\end{array}$ & $\begin{array}{l}(p H>5) \\
\text { (Locircumneutral in } \\
\text { in presence of } \\
\text { hydrogen sulfide) }\end{array}$ \\
\hline \multicolumn{5}{|c|}{ 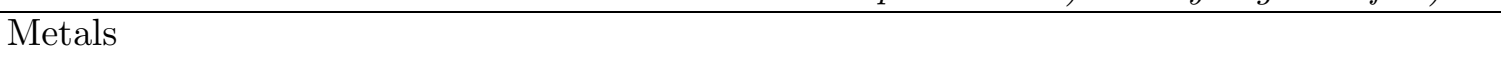 } \\
\hline & $\mathrm{Ag}$ - silver & $\mathrm{L}$ & $\mathrm{N}$ & $\mathrm{N}$ \\
\hline & $\mathrm{Al}$ - aluminum & M & $\mathrm{N}$ & $\mathrm{N}$ \\
\hline & As - arsenic & M & $\mathrm{N}$ & $\mathrm{N}$ \\
\hline & Ba - barium & $\mathrm{L}$ & $\mathrm{L}$ & M \\
\hline & Be - beryllium & $\mathrm{L}$ & $\mathrm{N}$ & $\mathrm{N}$ \\
\hline & $\mathrm{Cd}$ - cadmium & $\mathrm{H}$ & M & $\mathrm{N}$ \\
\hline & Co - cobalt & $\mathrm{H}$ & $\mathrm{L}$ & $\mathrm{N}$ \\
\hline & $\mathrm{Cr}$ - chromium & $\mathrm{L}$ & $\mathrm{N}$ & $\mathrm{N}$ \\
\hline & $\mathrm{Cu}$ - copper & $\mathrm{H}$ & $\mathrm{N}$ & $\mathrm{N}$ \\
\hline & $\mathrm{Hg}$ - mercury & M & $\mathrm{L}$ & $\mathrm{N}$ \\
\hline & $\mathrm{Ni}$ - nickel & $\mathrm{H}$ & $\mathrm{L}$ & $\mathrm{N}$ \\
\hline & Mn - manganese & M & $\mathrm{L}$ & M \\
\hline & Mo - molybdenum & $\mathrm{L}$ & $\mathrm{N}$ & $\mathrm{N}$ \\
\hline & $\mathrm{Pb}$ - lead & $\mathrm{L}$ & $\mathrm{N}$ & $\mathrm{N}$ \\
\hline & Se - selenium & M & $\mathrm{L}$ & $\mathrm{N}$ \\
\hline & Sb antimony & $\mathrm{L}$ & $\mathrm{L}$ & $\mathrm{N}$ \\
\hline & $\mathrm{Tl}$ - thallium & $\mathrm{L}$ & $\mathrm{L}$ & $\mathrm{L}$ \\
\hline & $\mathrm{V}$ - vanadium & M & $\mathrm{N}$ & $\mathrm{N}$ \\
\hline & $\mathrm{Zn}-\operatorname{zinc}$ & $\mathrm{H}$ & M & $\mathrm{N}$ \\
\hline \multicolumn{5}{|c|}{ Radioactive elements } \\
\hline & $\mathrm{Rn}$ - radon & $\mathrm{H}$ & $\mathrm{H}$ & half-life 3.8 days \\
\hline & U - uranium & M & $\mathrm{N}$ & $\mathrm{N}$ \\
\hline Airborne C & $\begin{array}{l}\text { ntaminants } \\
\text { asbestos } \\
\text { beryllium } \\
\text { dust containing met } \\
\text { dust containing solv } \\
\text { silica (quartz) }\end{array}$ & $\begin{array}{l}\text { als } \\
\text { ble salts }\end{array}$ & & \\
\hline
\end{tabular}

*Relative mobilities from Smith and Huyck (1999). 


\subsection{The sources of potentially harmful substances}

Potentially harmful substances (Table 2) can be concentrated through either natural or anthropogenic processes. Naturally occurring concentrations of potentially harmful elements may be located and characterized by standard mineral exploration methods. For example, metal sulfide mineral deposits (a natural source of heavy metals) are a logical target for a variety of electrical and electromagnetic methods. Evaluation of regional geological, geochemical, and geophysical data can be used to characterize regions as "favorable" for various types of mineral concentrations. Anthropogenic enrichments of potentially harmful substances may result from mining, milling, smelting, and disposal practices; examples include waste piles and abandonded mines.

\subsection{Mobility of potentially harmful substances}

Mobility is defined as the ease to which a substance is dispersed relative to the other materials surrounding it. There are chemical, physical, and biological factors which affect mobility (Rose and others, 1979).

Chemical factors influencing mobility relate to the chemical stability of an element in a solid phase relative to the coexisting mobile fluid phases. Table 2 summarizes relative conditional mobility of various potentially harmful substances in oxidizing or reducing chemical environments (Smith and Huyck, 1999).

A major physical factor affecting the mobility of potentially harmful substances is the surface area in contact with water because nearly all substances are soluble to some degree. New material is exposed to flowing water by natural processes such as uplift, fracturing of rocks, landslides, flooding, weathering (chemical or physical) and mechanical erosion as well as anthropogenic processes such as mining, dam construction, and road building. Another physical factor that affects mobility is the availability of potentially harmful materials to transport by wind. 
The overall mobility of a substance depends on the combination of all of these factors. In arid environments precipitation is sporadic, chemical weathering is episodic, and mechanical erosion may be a key factor in exposing substances to possible transport. A chemical pulse of dissolved minerals, enriched by weathering during dry periods commonly is associated with early spring runoff (Jeffries, 1991). This chemical pulse may carry metals in sufficient concentrations to harm aquatic life. Similarly, an intense chemical pulse can occur in areas of permafrost because concentrated brines that have developed during freeze/thaw cycles are released in the spring (William Miller, pers. comm., 1997). In tropical environments, high mechanical erosion can expose rocks to intense chemical weathering.

Important parameters that characterize the mobility of potentially harmful substances are largely those that relate to surface and subsurface hydrologic flow. Physical parameters include slope, relief, permeability, fracture or fault zones, clay and moisture content, tectonic regime and changes in tectonic stress, drainage network development, and stream flow. Chemical parameters include rock lithology/mineralogy, stream/ground water composition (i.e., pH, Eh), alteration, mineralogy of weathering products, and subsurface contaminant plumes. Biological parameters include the type and extent of biota.

\subsection{Transport of potentially harmful substances}

If a potentially harmful substance is mobilized, it may be transported by a variety of agents including wind, water, gravity and biota.

At the Earth's surface, wind can cause widespread dispersion of fine-grained materials. Very fine particles of asbestos, quartz, volcanic ash, metal-bearing dust, and dust containing soluble salts can be health hazards (Malcom Ross, pers. comm., 1996). Mineral dust may be transported by sandstorms in desert regions. It may be mobilized by drought or erosion. Transport can vary from short distances for particles larger than 100 
micrometers (saltation), to thousands of kilometers for particles less than 10 micrometers (Malcom Ross, pers. comm., 1996). Particulates can pose a particular problem in places, such as open-pit mines, mills, smelters or areas of recent landslide activity, where surficial materials are disturbed. Additionally, mine-waste materials that have been used locally in construction and as landfill increase the potential for further dispersal.

Water flow is the most important transport process available for moving potentially harmful substances. Both surficial and subsurface flows are important. Considerations of the pathways available to flow are discussed in Section 4.4. Discussion of the fluid flow itself is deferred to Section 5.2.

Gravity is the driving force behind the movement of surface water, but also plays a direct role in mass movements such as landslides, mine collapses, and dam failures. These mass movements may transport potentially harmful substances directly or may increase their mobility by exposing them to transport by wind or water.

Biologic transport of potentially harmful substances includes uptake and concentration of chemical elements by rooted plants, and bioaccumulation and magnification up the food chain by animals. Mobility may be enhanced by bacterial activity (Rose and others, 1979).

\subsection{Pathways for transport of potentially harmful substances}

Water flow, the most important transport process for contaminants in most situations, follows both surface and subsurface pathways. Surface pathways include existing rivers and streams, as well as ephemeral drainages in the form of gullies, arroyos, and washes. The size of channels, how deeply they are filled, and the conditions of the bottom surface may all control water flow rates. Under conditions of very heavy rainfall or when infiltration cannot keep up with precipitation, overland (sheet) flow may result in small (less than $10 \%$ ) portions of watersheds (Freeze and Cherry, 1979). Subsurface flow pathways are controlled by permeability and hydraulic head where flow is through porous or frac- 
tured media. Zones of well-sorted sand and gravel make excellent aquifers. Clay layers will retard subsurface water flow. In sedimentary materials, porosity, grain size, degree of sorting, cementation, fractures, and the presence of clay and alteration minerals are among the important factors controlling subsurface flow rates (Freeze and Cherry, 1979). In igneous and metamorphic terranes, fluid flow is usually dominated by fracture flow due to the lack of interconnected pore space.

\subsection{Interaction of potentially harmful substances with the environment}

Complex processes beginning at the source of potentially harmful substances and extending through the geologic environment to the biosphere and ultimately to humans provide multiple pathways for movement of harmful substances. Concentrations of toxic substances may be affected by physical dispersal; dilution; reduced drainage flow caused by ponding; freeze/thaw cycles in permafrost; interaction with highly weathered soil; changes in the water chemistry; movement along a geochemical gradient (see Section 5.1), or presence of a geochemical barrier (see Section 5.1). Processes most critical to humans are those that affect the food chain and drinking water quality including selective absorption by plants, grazing by livestock, uptake by biota, and contamination of aquifers.

\section{Processes Controlling Mineral-Environmental Problems}

To gain a complete understanding of a mineral-environmental problem we must examine the controlling physical, chemical, hydrological, and biological processes. For example, in the typical acid rock drainage scenario we must understand: (1) the geochemical reactions taking place in the mine (geochemical processes), (2) microbial processes that encourage or inhibit these reactions, (3) the fluid flow regime (hydrologic processes) that transports the acidic water, and (4) the effect of the acidic water on flora and fauna downstream (biologic/geologic interactions). In the following subsections, we review some critical 
aspects of the geologic, geochemical, physical, and biologic processes that affect mineralenvironmental problems. These processes are the link between mineral-environmental problems and the physical properties measured by the geophysical techniques.

\subsection{Geochemical processes}

Geochemical reactions control the release of many potentially harmful substances (Table 2 ) into the environment. The primary processes may be loosely subdivided into categories of "chemical weathering" and "deep alteration" (Krauskopf, 1979). Chemical weathering describes the process by which rocks and minerals formed at high temperature and pressure come to chemical equilibrium with water and air at near-surface conditions. Deep alteration describes the chemical interaction of rocks and ground water that take place at depth, usually at much higher pressures and temperatures.

Two important concepts in discussion of geochemical processes are geochemical gradients (gradual spatial changes in geochemical environment) and geochemical barriers (abrupt spatial changes in geochemical environment). Geochemical gradients may occur as a result of ore-forming (i.e., alteration) processes or as a result of surficial transport and subsequent deposition by wind or water. Geochemical barriers include mechanical, physiochemical, biochemical, and anthropogenic types (Smith and Huyck, 1999). These barriers may localize or confine various chemical weathering or alteration reactions leading to the accumulation of elements.

\subsubsection{Chemical Weathering (near-surface reactions)}

The primary processes that control chemical weathering (Krauskopf, 1979, p. 80) are: ionic dissociation, addition of water and carbon dioxide, hydrolysis, oxidation, and biological effects. The reactions of chemical weathering may take place slowly or rapidly and may or may not go to completion. If the reactions go to completion, the ultimate end products of chemical weathering are typically minerals stable under Earth-surface conditions including 
quartz, limonite, and kaolinite in the form of sand and clays.

The simplest form of chemical weathering, dissolution of soluble minerals and the addition of water, plays a major role in mineral-environmental problems. Since nearly all substances are soluble in water to some extent, the presence of any of the potentially harmful substances (Table 2) in rocks in contact with water can lead to finite levels of the substance in the water. This dissolution may be enhanced if acidic water is present.

Oxidation reactions, involving many sulfide minerals to produce acidic water, are of particular importance in mineral-environmental problems. A typical reaction is:

$$
2 \mathrm{FeS}_{2}+\frac{15}{2} \mathrm{O}_{2}+4 \mathrm{H}_{2} \mathrm{O} \rightarrow \mathrm{Fe}_{2} \mathrm{O}_{3}+4 \mathrm{H}_{2} \mathrm{SO}_{4}
$$

in which pyrite $\left(\mathrm{FeS}_{2}\right)$ is oxidized to produce ferric oxide (rust) and sulfuric acid. Oxidation by ferric iron $\left(\mathrm{Fe}^{3+}\right)$ in solution can enhance acid production, so sulfide-rich mineral deposits with high percentages of pyrite and ferric iron are particularly prone to generate acidic water (Plumlee and others, 1995). Bacteria catalyze acid production by converting ferrous $\left(\mathrm{Fe}^{2+}\right)$ to ferric iron (Smith, 1994).

Most rocks containing carbonates can provide a natural geochemical buffer for acidic waters. In contact with a strong acid, most carbonates such as calcite can dissolve and neutralize the acid. Mechanical erosion can increase the rates of acid production or consumption by breaking down the rock and increasing surface area available and exposing fresh mineral surfaces for reaction with the acidic waters.

\subsubsection{Deep alteration (reactions at depth)}

Alteration processes may play a role in mineral-environmental problems in regions where geothermal waters interact with surface waters. These geothermal waters may contain elevated concentrations of potentially harmful substances that have arisen from rock/water interactions that have taken place at higher temperatures and/or pressures than those typical of surficial weathering. 


\subsubsection{Microbial catalysis}

Microorganisms (principally bacteria) play a fundamental role in controlling the rates of many important weathering reactions including the principal oxidation reactions that produce acid rock drainage (Gould and others, 1994). In fact, Gould and others (1994, p. 185) state that acid mine drainage is "primarily the result of biological reactions." Bacterial growth is dependent on pH; values between 5 and 8 are best (Gould and others, 1994). Microorganisms (including algae, fungi, and yeasts in addition to bacteria) contribute to biological processes that are being investigated to ameliorate acid rock drainage (Gould and others, 1994).

\subsection{Fluid flow}

Fluid flow is probably the most important process of concern to mineral-related environmental problems because water provides the medium for the reaction and transport of potentially harmful chemicals from mineral deposits and the mechanism for the spread of these potentially harmful materials. Therefore, we must understand both surface and ground-water flows, how they are controlled by geology, and how these flows interact with each other and with mineral deposits and mine-waste materials.

Surface-water flows are controlled by topographic drainages and channels which dictate where water will flow and by topographic gradients which influence how fast the water will move. In addition, the depth of water, which is influenced by precipitation and infiltration rates, is an important factor. For example. increases in stream depth can result in flooding which can transport mine waste; these materials may be benign when dry, but become a contamination source when wet.

Ground-water flow is controlled by hydraulic conductivity and gradient. The former is a function of the physical properties of geologic materials, the manner in which they were deposited, and subsequent structural changes, whereas the latter depends upon dif- 
ferences in elevation (relief), availability of water (rainfall, infiltration, water levels in streams, rivers, and lakes), and degree of saturation (Freeze and Cheery, 1979). Variation in subsurface hydraulic conductivity is usually unknown when modeling subsurface fluid flow. Traditionally, determination of hydraulic conductivity is based on drill hole information, laboratory measurements, and numerical hydrologic model studies. However, in a hard-rock environment where hydraulic conductivity of the rock matrix is very low, fractures can dramatically increase fluid flow (Shapiro and Hsieh, 1991). The use of surface geophysics can greatly add to hydraulic conductivity mapping by correlating measurements to well information, and then using the geophysical measurements to provide information about the areas between wells.

Understanding the interaction of surficial water and ground water is becoming increasingly important (Nagorski, 1997; Winter and Woo, 1990).

\subsection{Biologic/geologic interactions}

Vegetation can have a profound effect on the dispersion of potentially harmful substances in surficial deposits. Elements may be solubilized by complex biogenic processes from relatively stable mineral phases and ingested into a plant. Plants create an extremely corrosive environment in the vicinity of their root tips that enables the extraction of metals and other mineral matter from the soil (Rose and others, 1979, p. 459). Substantial quantities of inorganic matter may ultimately reside in the body of the plant. As leaves and other parts of the plant fall to the ground and decay, these elements are susceptible to leaching or are recycled in the soil for subsequent uptake.

Although plants may absorb small amounts of most elements, several elements which are toxic at high concentrations, (e.g., $\mathrm{Cu}, \mathrm{Zn}, \mathrm{Mo}$, and $\mathrm{Mn}$ ) are required for the health of most plants at lower levels (Rose and others, 1979). 


\subsection{Energy flow}

In many cases the flow of energy in mineral-environmental problems is studied as part of other processes such as fluid flow (where flow of heat may be considered), or geochemical processes (where heats of reaction may be important). In some cases, however, it may be advantageous to consider the flow of energy (for example, as heat) separately. For example, the exothermic oxidation of pyrite which is expected in mine waste-rock dumps, should cause a temperature rise of from $2^{\circ} \mathrm{C}$ to $20^{\circ} \mathrm{C}$, depending on the amount of oxygen transport in the system (Ritchie, 1994); measurement of temperature profiles can be an effective way to monitor oxidation rate. Another example is underground coal fires in which energy (thermal and chemical) release can be extreme; such fires can be locally detected with airborne thermal surveys. Repeat temperature measurement in boreholes (measurement of energy flow) can be used to monitor rates of certain chemical reactions in mine-waste piles. In other applications, energy (either heat/temperature or mechanical) may contribute to an environment that enhances or inhibits important geochemical or biological processes.

\subsection{Mass movement}

Several natural and anthropogenically induced processes provide mechanisms for moving large quantities of mine-waste materials over distances ranging from tens of meters to several kilometers or more. Mass movement by landslide, avalanche, mine collapse, and flood can produce physical hazards and can result in placement of mine-waste materials into new environments. Remediation efforts may also move materials into areas prone to mass movement.

Mine collapse can cause mass movement through down-dropping of material above a mine. The processes involved and the form that the collapse takes is dependent upon the host-rock geology (Lee and Abel, 1983) and the style of mining. Most mine collapse 
studies have been concerned with subsidence over coal deposits (Dunrud, 1976; Allen, 1978; Shadbolt, 1978; Carpenter and others, 1995). In hard-rock mining, rock collapse progresses upward from the mined zone as ore is removed. The collapse will not cause surface deformation until the upward-stoping process has thinned the intact rock so that it can no longer support the weight of the overburden (Lee and Abel, 1983). The cave-in breaches the surface, typically in the form of a circular depression or chimney, with rock adjacent to the chimney sliding into it. Collapse can take place contemporaneously or more than a decade after mining activity has stopped (Lee and Abel, 1983; Hobba, 1993).

Mine collapse can have more profound effects on the local hydrologic regime. Mine collapse can produce fissures in the ground, that eventually reach the surface, providing a pathway for the migration of surface water to depth (Lee and Abel, 1983; Hobba, 1993). Likewise, subsurface fracturing increases subsurface hydraulic conductivity. Both of these actions can greatly increase the mobility of contaminants, due to chemical and physical effects, as well as modifying regional ground-water flow patterns.

Landslides resulting from slope failure triggered by precipitation, increased groundwater flow, or earthquakes can transport large quantities of material. In addition, the scar left by the landslide will expose new material to erosion and chemical weathering processes. Given the right conditions, a buried, benign mineral deposit containing potentially harmful substances, can be quickly transformed into a newly exposed contamination source. Landslides and avalanches that originate above mine dumps can rapidly transport mine-waste materials into new areas where they may pose a hazard. In a similar fashion, floods (caused either by heavy precipitation or dam failure) can transport mine waste, depositing it far down stream and spreading the contaminants. 


\section{Description of Geophysical Techniques}

In this section we discuss geophysical techniques with known or possible application to understanding of the processes and problems discussed in the previous two sections. In each subsection we highlight the following topics:

- Physical property (or properties) that the technique is sensitive to

- Invasiveness of the technique

- A typical application to a mineral-environmental problem

- Sub-specialty techniques

- Typical measurement sensitivities for the technique

- Possible problems or limitations of the technique

- Promising research directions

The use of geophysical methods for environmental studies differs from their use for exploration because limitations are commonly imposed by the need to preserve environmental conditions at the site and thus minimize or restrict invasion and disturbance of the site. Remote sensing data from satellite and aircraft are the least invasive and do not pose a problem in this regard. Low flying aircraft used to acquire magnetic, radiometric, and electromagnetic data are usually only restricted by special circumstances. Groundbased measurements (gravity, VLF, electromagnetic induction) involve access constraints similar to those for geologic mapping. Electrical surveys involving the insertion of probes (DC resistivity, IP, SP) may be a problem if, for example, a clay cap overlaying a mine dump is to be preserved. Seismic methods requiring an explosive charge are significantly constrained in some areas (e.g., prohibited in National Parks; not employed where explosive gases such as methane may be present). There are alternative energy sources such as 
vibrators or, for local studies, sledge hammers which can be employed. Borehole methods (heat flow; electromagnetics and hole-hole and hole-surface seismic) are the most invasive and hence most restricted because they can produce pathways for contaminant transport. Where boreholes already exist at the site the methods may still be employable if the well construction and geometry are appropriate.

\subsection{Electrical and electromagnetic methods}

Electrical and electromagnetic (EM) geophysical methods can be used to map subsurface variability in electrical properties caused by changes in lithology, alteration, temperature, and fluid content such as contamination due to mining activity. Because silicate minerals are insulators under near surface temperatures and conditions, electrical current flow in geologic materials is confined to fluids or clays in the pore space. Therefore, the porosity, fracture density, pore fluid resistivity, degree of saturation, and clay content, are the primary factors controlling the bulk resistivity. A more complete explanation of these key factors affecting resistivity may be found in Keller and Frischknecht (1966).

Drainage water in poorly buffered environments from sulfide ore bodies, mines, and mine dumps are characterized by high total dissolved solids (TDS) and low $\mathrm{pH}$ (2.5 or less, Plumlee and others, 1992; 1999; Plumlee, 1999). This results in water with very high specific conductivity (500-38,000 $\mu \mathrm{S} / \mathrm{cm}$, typically 1,000-6,000 $\mu \mathrm{S} / \mathrm{cm})$. Whereas the response of most electrical geophysical methods are not ion specific, they are very sensitive to these high conductivity targets. Accordingly, electrical and electromagnetic methods can be used to map the location and migration of mine drainage waters containing high TDS.

There are a wide variety of traditional electrical geophysical techniques that can be used for mapping of mine-waste. These methods are characterized by: 1) the type of source and sensor (direct current or resistivity, electromagnetic induction, plane wave methods 
such as magnetotellurics and VLF resistivity, and radar), and 2) the measurement platform (ground, airborne, or borehole). For a complete summary of the many methods and their characteristics, references such as Keller and Frischknecht (1966), Grant and West (1965), Nabighian (1988, 1991), and Wait (1982) should be consulted. Experience with the use of electrical geophysical methods in mapping of mine waste is limited. However, literature is growing on the use of these techniques for ground-water and environmental problems (Ward, 1990).

The user of electrical methods must keep in mind the depth to which information can be obtained and the resolution of each method. For electrical and electromagnetic methods the depth of investigation can range from less than a meter in the case of ground penetrating radar in clayey or very conductive terrains to tens and hundreds of meters for most other methods, and it can be adjusted for a particular survey need. Resolution of targets and detectability tend to decrease with increasing depth of burial.

Cultural noise is another consideration for electrical methods. The presence of power lines and radio transmitters can produce increased electromagnetic noise which reduces the sensitivity and resolution of many electrical methods. Metallic objects such as fences, buried pipelines and cables, well casings, and metallic debris from abandoned or buried mining operations often produce signals that may complicate or confound electrical and electromagnetic data interpretation due to the highly irregular 3-D response of these objects. Whereas there is no universal way of predicting or eliminating the noise response of such bodies, there are means by which their influence can be recognized and reduced.

The foregoing discussion has focused on methods that are primarily sensitive to changes in bulk resistivity without discriminating between the presence of different minerals. The induced polarization method, developed for disseminated sulfide exploration, can differentiate under certain circumstances between various metallic sulfide and alteration minerals. This technique holds promise as a means of characterizing mine-waste deposits. 
Likewise, the self-potential method may be of use in studying waste piles because it responds to the presence of electrochemical cells and water flow in the ground. These two areas deserve further research.

\subsection{Seismic methods}

Seismic methods are often subdivided into reflection, refraction, and direct-wave categories based on the path that seismic waves take from source to receiver. For shallow studies, typical seismic energy sources include sledge hammers, weight dropping devices, small explosive sources (shotgun shells), or mechanical vibrators. There are two main kinds of waves used in seismic studies that travel at different velocities: "P" waves and "S" waves (primary and secondary, or push and shake). Sometimes the ratio of these two velocities (Poisson's ratio) can be diagnostic of the material transmitting the seismic energy.

Depending on the strength of the seismic source and geometry of the experiment (distance from source to receivers, distance between receivers), seismic measurements can yield very detailed subsurface maps. Depth accuracies can range from $\pm 1 \%$ to $\pm 10 \%$.

Seismic methods are sensitive to variations in the elastic properties and density of the subsurface. Shallow Earth materials display a range of elastic properties, and seismic methods can be used to map important geologic, hydrologic, and physical interfaces including the base of the surficial weathering layer, the water table, and stratigraphic or structural breaks between contrasting rock units.

For shallow environmental studies, seismic methods can help define groundwater pathways including faults, fractures, and stratigraphic boundaries. The geometry of the seismic experiment can be tailored to the type of structural information required. Seismic experiments conducted at the surface are most sensitive to sub-horizontal layers. Seismic experiments may also be conducted in other geometries, such as between boreholes. This configuration uses direct-wave travel times and can be interpreted, using tomography, to 
give a very detailed reconstruction of the ground, similar to those produced for medical imaging.

Typical surface-based seismic methods are most effective in regions with sub-horizontallylayered interfaces. Complicated, three-dimensional structure can be very difficult to interpret unless data can be collected using sources or receivers below ground (i.e., in boreholes or underground mine workings/tunnels). In regions with loose, unconsolidated surficial material, such as gravel, it can be difficult to transmit seismic energy into the ground. Accuracy of seismic interpretation is also limited by the presence of ambient noise such as heavy truck traffic, wind (which affects the ground through the shaking of trees and other vegetation), or ocean surf.

Areas for research and development in the application of seismic methods to shallow environmental problems include development of new mechanical seismic sources, experimentation with different source/receiver geometries for different types of targets, and development of software for processing and imaging seismic data and for integrating seismic data with other subsurface information.

\subsection{Thermal methods}

Thermal methods detect the production and movement of heat in the Earth. Accurate measurement of conductive heat flux requires precise measurement of subsurface temperatures (usually in boreholes), and thermal conductivity (usually made in the laboratory on samples from boreholes). Understanding temporal changes in temperature and heat flow requires knowledge of the thermal diffusivity. The main sources of heat in the upper several kilometers of the Earth include the convective movement of hot fluids including geothermal waters and magma, as well as the radioactive decay of uranium, thorium, and potassium. At the surface, solar heating dominates and various chemical reactions can also be important contributors. 
Temperature measurements for thermal studies are typically invasive, conducted in boreholes or by penetration of sediments by a probe. Non-invasive surface-temperature measurements can be made by aircraft and satellite. Other non-invasive thermal measurements could be made with specialized equipment, either with available instrumentation or with minimal development. For example, heat flow at the surface could be measured by spreading a "blanket" of known thermal conductivity and measuring the equilibrium temperatures above and below.

Temperature is an important variable for a host of geochemical processes, so knowledge of subsurface temperatures may be useful in understanding environmental problems. Subsurface temperature is a function of available heat sources, and the mode and paths of heat flow through the region. The two primary modes of heat flow in the Earth are conduction and convection. In a conductive regime, the distribution of temperature with depth is a function of thermal conductivity and heat production. In a convective regime, the distribution of temperature with depth (in the shallow subsurface) is a function of the movement of water through the region; in these systems analysis of borehole temperature can be used to infer amount and direction of water movement. Subsurface temperatures can change as a result of changing boundary conditions at the Earth's surface (such as changes in mean surface temperature or changes in precipitation). The subsurface changes will lag in time behind changes in the surface conditions. This transient behavior can be used to measure changes in factors such as average surface temperature or rate and temperature of water flow.

Temperature versus depth measurements are generally made in boreholes by lowering a sensitive thermistor on a logging cable. Measurements may be made in unconsolidated sediments using a rigid probe. Ocean-bottom and lake-bottom measurements are commonly made by penetrating sediments in this way. Temperature versus time measurements can be made on fixed thermister strings installed in a borehole or with a network 
of shallow probes spread over an area.

With modern equipment and techniques, temperatures can be measured to millidegree precision. Accuracy of heat flow determination is limited generally by knowledge of thermal conductivity and by convection of fluid within the measurement borehole.

Possible research directions for thermal methods include development of monitoring techniques for geochemical reactions in mine tailings ponds, integration of borehole temperature measurements with thermal information from remote sensing data, and application of thermal measurements to three-dimensional models of fluid flow.

\subsection{Remote sensing methods}

Remote sensing involves the use of images acquired from aircraft and satellites for mapping and monitoring the Earth's surface. These images typically record electromagnetic energy, either reflected or emitted. Modern remote sensing began with the LANDSAT satellites in 1972. These satellites recorded reflected energy in the visible and near infrared parts of the spectrum. Thematic Mapper (TM) data, first collected in 1982 on the second generation LANDSAT satellites, is of particular interest for mineral-environmental applications; despite its fairly broad spectral bands (roughly 100nm), it can be used to group minerals in two broad classes: (1) iron oxides and (2) clays/carbonates at $30 \mathrm{~m}$ spatial resolution. In addition one channel is used to record emitted energy that is related to surface temperature. There are also new satellite systems planned for launch shortly with improved spatial (1-5m) and spectral (10nm) resolution. Greater spatial resolution improves detection of small features (such as tailings piles) and reduces classification errors due to mixing signals from adjacent objects. Finer spectral resolution makes it possible to improve identification from groups of minerals (e.g., iron oxides) to individual minerals (e.g., hematite, goethite, and jarosite).

Aircraft data can now be acquired to map surface mineralogy, lithology, temperature, 
and vegetation state in order to support environmental and geotechnical studies. Airborne imaging spectroscopy, a method that acquires reflected radiation from the ground with a spectral resolution comparable to laboratory spectrometers (10nm) for mapping a wide variety of minerals (iron-bearing minerals, phyllosilicates, carbonates, sulfates), vegetation species, and vegetation stress has been shown to be a powerful tool for mapping ground alteration and detecting lithologies that can act as buffering agents. Airborne multispectral thermal scanners that detect radiation emitted from the ground can be used to measure both spectral emissivity (analogous to reflectivity) and temperature, and have been used to map igneous lithologies, silicic alteration, and to detect exothermic reactions in waste piles as a measure of the presence of pyrite (Watson and Rowan, 1996).

An excellent example of the use of imaging spectroscopy is the mapping of acidgenerating minerals from aircraft at the EPA Superfund site in Leadville, CO (Swayze and others, 1996). The waste piles were shown to have small zones of jarosite surrounded by jarosite-goethite zones, which in turn were surrounded by goethite and hematite zones. Field checking indicated that the small jarosite zones are pyrite-rich, and that oxidized coatings on fine-grained pyrite was detected by identifying and mapping the sulfate mineral jarosite. Areas covered by jarosite and jarosite-goethite mine waste are believed to have higher acid generating capacity and 20-100 times higher metal mobility than those areas covered by goethite and hematite. These results indicate that imaging spectroscopy can be used to map specific minerals that indirectly indicate $\mathrm{pH}$ conditions under which they were formed and to locate sources of acid rock drainage.

Airborne spectral thermal infrared data are particularly effective for detecting silica rich rocks and have been used to map silicic alteration (Watson and others, 1990). Broadband thermal data can be used to detect surface temperature differences as small as $0.1^{\circ} \mathrm{C}$ at spatial resolutions as fine as $5 \mathrm{~m}$. A recent study has reported that heat associated with pyrite oxidation and subsequent combustion of bituminous shale in waste piles was de- 
tected using an airborne thermal scanner (Kuehn and Hoerig, 1996). There are plans to acquire comparable spectral data from satellite by 1998, however the initial spatial resolution will be low $(90 \mathrm{~m})$; there is also a NASA proposal to acquire $20 \mathrm{~m}$ resolution thermal (broadband) data from satellite by 2001 .

Limitations of remote sensing include (1) the inability to detect mineralogic/lithologic changes where vegetation cover is high (causing both a masking effect and spectral contamination), (2) the difficulty of sorting out exothermic heating effects from residual solar/topographic effects, (3) lack of penetration below the ground surface and thus high sensitivity to weathering, the (4) limited availability of airborne data, and (5) mixing effects caused by inadequate ground resolution. There are a wide variety of instruments and platforms available to address topical to regional scale problems. Cost-effective use requires knowledge of the capabilities and experience in their use.

New developments include satellite data at spectral and spatial resolutions comparable to current airborne systems, satellite radar interferometry to measure centimeter-scale ground movements, and improved spectral resolution for airborne thermal systems that should improve silicate mineral identification.

\subsection{Potential fields methods}

Gravity and magnetic methods in exploration geophysics share a common mathematical foundation based on classical potential field theory (Blakely, 1995). Because of this common basis, these methods share many strengths and weaknesses. Despite their theoretical similarity, however, these methods commonly play very different roles in geological interpretation because each is sensitive to fundamentally different physical rock properties. The gravity method reveals information about the distribution of density, a bulk property of Earth materials. The magnetic method, in contrast, is sensitive to the distribution of magnetic minerals (the most important of which are magnetite, $\mathrm{Fe}_{3} \mathrm{O}_{4}$, and 
its solid solutions with ulvospinel, $\mathrm{Fe}_{2} \mathrm{TiO}_{4}$ ) that are typically trace constituents of rocks and sediments.

To the extent that the distributions of density or magnetization reflect geologically significant features, interpretation of gravity and magnetic data can yield important threedimensional information about the distribution and structure of these features. For example, gravity data can be used to model the shape of a basin containing young (typically low density) sedimentary rocks juxtaposed against (typically higher density) basement rocks. Interpretation of magnetic data could provide complementary information in this situation if there is a magnetic contrast between the sedimentary rocks and the basement rocks, which is commonly the case. Mapping of the sediment/basement interface can be important in understanding subsurface water movement.

Even in cases when there is insufficient information available to warrant detailed twoor three-dimensional modeling of potential field data, important conclusions can be drawn about geologic structure, and structural trends can be deduced by examination and analysis of potential field images. For example, faults may often be traced by mapping offsets of both gravity and magnetic source bodies.

Magnetic data are also sensitive to man-made magnetic objects such as pipelines, well casings, and buried metal drums. This sensitivity is important for applications such as finding abandoned wells and buried drums, locating and mapping waste dumps, and hunting for unexploded metallic ordinance. Gravity data have a more limited application, but detailed surveys can be used to locate shallow air-filled chambers such as buried mine shafts or culverts. In theory, closely spaced gravity measurements could be used to locate shallowly buried empty (or partly filled) drums. In practice, however, the expected anomalies are so small that they would be difficult to distinguish from noise using present instrumentation and data reduction methods.

Repeat gravity or magnetic measurements can provide low-cost, non-invasive monitor- 
ing of subsurface processes. High-resolution repeat gravity measurements may be used to track changes in the water table or movement of unstable slopes. Magnetic measurements can be used to monitor movement of placed magnets (buried for the purpose of tracking settling or instability), or processes that create or destroy magnetic properties (such as high-temperature fluid injection which could locally raise temperatures above the Curie point where stable magnetization can exist for a given mineral).

Borehole gravity measurements yield accurate bulk rock densities. Combined with laboratory measurements on core samples, or with information from other borehole logs, these bulk densities can be used to deduce bulk porosity, an important hydrologic variable.

Possible research directions for potential field methods include development of improved interpretation techniques, particularly for three-dimensional interpretation and integration with other data sets, and development of survey techniques for high-resolution measurements of small areas.

\subsection{Other geophysical methods}

A number of methods listed in Table 1 are not discussed in the previous sections. These include microwave (active and passive), borehole logging, GPS repeat surveying, laboratory measurements, and radiometrics. Active microwave techniques including SLAR (side-looking airborne radar) and SAR (synthetic aperture radar) provide information on surface texture, moisture, and vegetation cover. Current geographic coverage is limited. Passive microwave measurements can also be made at comparable wavelengths $(\mathrm{cm}$ to m) much in the same fashion as broad band thermal (both refer to emitted radiation from the ground). The microwave region provides deeper penetration of the ground (typically meters) that can be useful for examining near surface heating (at depths below the daily surficial changes) and detecting dielectric property changes that are associated with dry versus wet ground and frozen versus unfrozen ground. The limitation is low spatial 
resolution (passive satellite systems have spatial resolution in the tens of kilometers in contrast to active systems which can be better than $10 \mathrm{~m}$ ). Borehole logging includes virtually all geophysical methods that can be conducted on the ground and provide detailed measurements for determining physical rock properties in a depth profile. In addition, measurements can be made between holes or between the surface and the borehole to provide a 3-D characterization (LaBrecque and Ward, 1990; Lo and Inderwiessen, 1994). The method is extremely valuable for exploration, but, because it is highly intrusive, use is often restricted in environmental studies. Repeat surveys or long-term base-station monitoring using GPS receivers can be used in differential mode to track very small Earth movements between stations to measure subtle ground movements which might be precursors of landslides or other hazardous ground movement. Laboratory measurements refers to the empirical characterization of physical rock properties such as porosity and permeability and their relationship to other physical rock properties that are directly measured. Radiometrics, commonly referred to as gamma ray spectrometry, is employed from airborne platforms, hand held instruments, or downhole logging to measure the radioactivity of the ground. Airborne surveys have been used to estimate abundances of potassium, thorium, and uranium for a variety of activities including regional lithologic discrimination, mineral exploration, and environmental background studies (Nielsen and others, 1990; Greg and Holmes, 1990; Darnley and Ford, 1989; Graham and Bonham-Carter, 1993; Dernley, 1993; Smith, 1985; Raghuwanshi, 1992; Duval, 1989; 1991).

\section{Glossary of Terms}

Acid rock drainage - Acidic water, often rich in heavy metals, which results from interaction of oxygenated surface water (rainwater, snowmelt, pond water) and shallow subsurface water with many types of rock that contain sulfur-bearing minerals. 
Alteration - A general term to describe a group of geochemical reactions (including oxidation, hydration, and hydrolysis) that modify the original composition of a mineral.

DC resistivity method - A geophysical method for determining subsurface resistivity (to infer geologic structure and stratigraphy) by injecting a direct current into the ground and measuring the voltage produced at various locations.

Electromagnetic induction method - A geophysical method that uses a time-varying, controlled, current source and measures the resulting electric and/or magnetic fields to determine subsurface resistivity (to infer geologic structure and stratigraphy). The method can be used with a variety of frequency ranges and sources.

Electromagnetic methods (EM) - A class of geophysical methods using measurement of electric and magnetic fields associated with currents in the subsurface (to infer geologic structure and stratigraphy). The methods include both controlled and natural sources.

Geoenvironmental studies - Work that furthers the understanding of environmental characteristics of geological materials, both in natural and man-made settings.

Geographic information system (GIS) - A computer system of software and hardware that enables the user to store, retrieve, and interact with map-based data.

Gravity method - A geophysical method that uses measurements of the spatial variation of the force of gravity as a way to infer variations of density in the subsurface.

Ground penetrating radar (GPR) - A high-resolution electromagnetic geophysical technique operating in the megahertz frequency range which propagates electromagnetic waves into the ground and records the waves reflected by electrical property bound- 
aries (dielectric permittivity and conductivity). The depth of investigation is limited by highly conductive materials such as mineralogical clays.

Induced polarization method (IP) - A geophysical method used to map the presence of disseminated metallic grans and clays involving the measurement of electrical polarization which occurs at pore fluid-metallic mineral grain boundaries when an electrical current is passed through the material. Induced polarization can also be produced by clay-filled pore spaces. This phenomenon results in a frequency dependent electrical resistivity, which is commonly diagnostic of the minerals present.

Imaging spectroscopy - A technique to map individual minerals using reflected solar light over many very narrow spectral channels. Current systems have spectral widths of $10 \mathrm{~nm}$ and 224 channels, operated from aircraft with spatial resolutions ranging from $20 \mathrm{~m}$ to $3 \mathrm{~m}$.

Magnetic method - A geophysical method that employs measurements of the Earth's magnetic field to infer the distribution of magnetic minerals (most importantly magnetite) in the subsurface.

Multispectral scanner - A satellite or aircraft system that measures reflected light in several channels, typically with spectral resolutions of about 100nm. Spatial resolution of the systems are typically $5-30 \mathrm{~m}$. Multispectral scanner systems often include a thermal infrared channel to measure the emitted ground radiation in order to estimate surface temperature.

Radiometric method - A geophysical method that involves measurement and interpretation of natural radioactivity produced primarily by the elements uranium, thorium, and potassium. 
Self-potential method (SP) - A geophysical method that measures changes in the natural voltage between two electrodes in the ground. It can be used to map shallow sulfide bodies and is also sensitive to fluid flow and subsurface temperature gradients.

Side-looking airborne radar (SLAR) - A radar signal is transmitted from an antenna on an aircraft and the energy backscattered from the ground is recorded. A SLAR database exists for parts of the United States at the USGS EROS Data Center.

Spectral thermal method - A multispectral technique which operates in the thermal infrared region of the electromagnetic spectrum to map rock-forming minerals (primarily silicates). Current systems (e.g., NASA-Thermal Infrared Multispectral Scanner) operate from aircraft with a spectral resolution of 75-100nm and spatial resolutions of $5-25 \mathrm{~m}$.

Synthetic aperture radar (SAR) - A technique used to acquire high-spatial resolution radar data by adding together multiple signals acquired at different time instants.

Time-domain reflectrometry (TDR) - An electromagnetic measurement technique that uses electromagnetic pulses transmitted along a probe pushed into the ground to measure soil moisture.

Tomography - The use of measurements made by passing some form of energy through an object to make a two- or three-dimensional image of the internal structure of the object.

Very low frequency electromagnetic method (VLF) - A ground or airborne electromagnetic geophysical method that uses distant radio transmissions $(3-30 \mathrm{kHz})$ and measures changes in the tilt of the electromagnetic field to map near-surface conductors. A variant of this method called VLF-R is used to map subsurface resistivity. 


\section{References}

Allen, A. S., 1978, Basic questions concerning coal mine subsidence in the United States: Association of Engineering Geologists Bulletin, v. 15, no. 2, p. 147-161.

Blakely, R.J., 1995, Potential Theory in Gravity and Magnetic Applications: New York, Cambridge University Press, 441 p.

Carpenter, P. J., Booth, C. J., and Johnston, M. A., 1995, Application of surface geophysics to detection and mapping of mine subsidence fractures in drift and bedrock: Illinois State Geological Survey Report, 21 p.

Darnley, A.G., 1993, Some notes on the importance of airborne gamma-ray spectrometry in international geochemical mapping: Jour. Geochemical Exploration, v. 49, n. 1-2, p. 201-212.

Darnley, A.G., and Ford, K.L., 1989, Regional airborne gamma-ray surveys: A review, p. 229-240. in Proceedings of Exploration 87: Third Decennial International Conference on Geophysical and Geochemical exploration for mineral and groundwater, edited by G.D. Garland, Ontario Geological Survey, Special Volume 3, 960p.

Dunrud, C. R., 1976, Some engineering geologic factors controlling coal mine subsidence in Utah and Colorado: U.S. Geological Survey Professional Paper 969, 39 p.

Duval, J. S., 1989, Radioactivity and some of its applications in geology, Proceedings of the Symposium on the Application of Gephysics to Engineering and Environmental Problems SAGEEP 89, March 13-16, 1989, Golden, Colorado, p. 1-6.

Duval, J.S., 1991, Use of aerial gamma-ray data to estimate relative amounts of radon in soil gas: in USGS Bulletin 1971, p. 155-162. 
Freeze, R. A. and Cherry, J. A., 1979, Groundwater: Englewood Cliffs, New Jersey, Prentice Hall, 604 p.

Graham, D.F. and Bonham-Carter, G.F., 1993, Airborne radiometric data: A tool for reconnaissance geologic mapping using GIS: Photo. Eng. And Remote Sensing. v. 59, n. 8, p. 1243-1249.

Grant, F.S., and West, G.F., 1965, Interpretation theory in applied geophysics: New York, McGraw-Hill, 584 p.

Gregg, L. T., and Holmes, J. J., 1990, Radon detection and measurement in soil and groundwater, in Ward, S. H., ed., Geotechnical and Environmental Geophysics, v. I, Review and Tutorial: Tulsa, Society of Exploration Geophysicists, p. 251-262.

Herschbach, D., 1997, Chemistry: Blithe sibling of physics, Physics Today, v. 50, n. 4, p. $11-13$.

Hobba, W. A., Jr., 1993, Effects of underground mining and mine collapse on the hydrology of selected basins in West Virgina: U.S. Geological Survey Water Supply Paper 2384, 79 p.

Hoover, D.B., Klein, D.P., and Campbell, D.C., 1995, Geophysical methods in exploration and mineral environmental investigations, in DuBray, E. (ed.) Preliminary compilation of descriptive geoenvironmental mineral deposit models, U.S.Geological Survey Open-File Report 95-831, p. 19-27.

Jeffries, D.S., 1991, Snowpack storage of pollutants, release during melting, and impact on receiving waters: in Acidic Precipitation - Soils, Aquatic Processes, and Lake Acidification, v. 4, Norton, S.A., Lindberg, S.E., and Page, A.L. (eds), p. 107-128. 
Keller, G.V., and Frischknecht, F.C., 1966, Electrical methods in geophysical prospecting: International Series of Monographs in Electromagnetic Waves: Oxford, Pergamon, 519 p.

Krauskopf, K.B., 1979, Introduction to Geochemistry (second edition): San Francisco, McGraw-Hill, 617 p.

Kuehn, F. and Hoerig, B., 1996, Thermal remote sensing for assessing mine tailings, Eleventh Thematic Conference on Applied Geologic Remote Sensing, Las Vegas, NV,

LaBrecque, D. J., and Ward, S. H., 1990, Two-dimensional cross-horehole resistivity model fitting, in Ward, S. H., ed., Geotechnical and Environmental Geophysics, v. I, Review and Tutorial: Tulsa, Society of Exploration Geophysicists, p. 51-74.

Lee, F. T., and Abel, J. F., Jr., 1983, Subsidence from underground mining: environmental analysis and planning considerations: U.S. Geological Survey Circular 876, $28 \mathrm{p}$.

Lo, Tien-when, and Inderwiessen, P., 1994, Fundamentals of seismic tomography: Tulsa, Society of Exploration Geophysics, 120 pp.

Nabighian, M.N., [Ed.], 1988, Electromagnetic methods in applied geophysics: Tulsa, Soc. Expl. Geophys., v. 1, 503 p.

Nabighian, M.N., [Ed.], 1991, Electromagnetic methods in applied geophysics: Tulsa, Soc. Expl. Geophys., v. 2, 992 p.

Nagorski, S.A., 1997, Impacts by acidic, metals-rich groundwater on the hyporheic zone of an intermontane stream: unpublished M.S. Thesis, University of Montana. 
Nielson, D. L., Linpei, C., and Ward, S. H., 1990, Gamma-ray spectrometry and radon emanometry in environmental geophysics, in Ward, S. H., ed., Geotechnical and Environmental Geophysics, v. I, Review and Tutorial: Tulsa, Society of Exploration Geophysicists, p. 219-250.

Paterson. N., Robertson, D., Hearst, R., Stanton-Gray, R., Miller, E. and Silverthorn, S., 1994, Application of remote sensing and geophysics to the detection and monitoring of acid mine drainage: MEND Project \#4.6.3, CANMET Library, 562 Booth St. Ottawa, Ont., 118 p.

Plumlee, G.S., 1999, The environmental geology of mineral deposits, Chapter 3, in Plumlee, G.S., and Logsdeon, M.J., eds., The Environmental Geochemistry of Mineral Deposits, Part A: Processes, Techniques, and Health Issues, Reviews in Economic Geology, Vol. 6A: Littleton, Colorado, Society of Economic Geologists, Inc., P. 71-116.

Plumlee, G.S., John, D.A., and Hammarstrom, J.M., 1995, Geoenvironmental models of mineral deposits - fundamentals and applications: in Du Bray, E. (ed.), Preliminary compilation of geoenvironmental deposit models, USGS Open File report 95-831, p. $1-9$.

Plumlee, G.S., Smith, K.S., Ficklin, W.H., and Briggs, P.H., 1992, Geological and geochemical controls on the composition of mine drainages and natural drainages in mineralized areas: Proceedings, 7th Intl. Water-Rock Interaction Conference, Park City, Utah, July 1992, p. 419-422.

Plumlee, G.S., Smith, K.S., Montour, M.R., Ficklin, W.H., and Mosier, E.L., 1999, Geologic controls on the composition of natural waters and mine waters draining diverse mineral-deposit types: Chapter 19, in Filipek, L.H., and Plumlee, G.S., 
eds., The Environmental Geochemisty of Mineral Deposits, Part B: Case Studies and Research Topics, Reviews in Economic Geology, Vol. 6B: Littleton, Colorado, Society of Economic Geologists, Inc., p. 373-432.

Raghuwanshi, S.S. 1992, Airborne gamma-ray spectrometry in uranium exploration: COSPAR 28th plenary meeting; Remote sensing of the Earth's surface and atmosphere, Advances in Space res., v. 12, n. 7, p. 77-86.

Ritchie, A.I.M., 1994, The Waste-rock Environment, Chapter 5, in Short Course Handbook on Environmental Geochemistry of Sulfide Mine-Wastes, Jambor, J.L., and Blowes, D.W., eds., Mineralogical Association of Canada, p. 133-162.

Rose, A.W., Hawkes, H.E., and Webb, J.S., 1979, Geochemistry in Mineral Exploration: Academic Press, New York, 657 pp.

Shadbolt, C. H., 1978, Mining subsidence-historical review and state of the art, in Geddes, J. D., ed., Conference on large ground movements and structures: Cardiff, Wales, July 4-7, 1977, Proceedings, p. 705-748.

Shapiro, A. M., and Hsieh, P. A., 1991, Research in fractured-rock hydrogeology: Characterizing fluid movement and chemical transport in fractured rock at the Mirror Lake drainage basin, New Hampshire, in Mallard, G. E., and Aronson, D. A., eds., U.S. Geological Survey Toxic Substances Hydrology Program-Proceedings of the technical meeting, Monterey, California, March 11-15, 1991: U.S. Geological Survey Water-Resources Investigation Report 91-4034, p. 155-161.

Smith, R.J., 1985, Geophysics in Australian mineral exploration: Geophysics, v. 50, n. 12, p. $2637-2665$.

Smith, K.S., 1994, Generation and interactions of mine drainage at the Argo Tunnel, in Guidebook on the Geology, History, and Surface-Water Contamination and Reme- 
diation in the Area from Denver to Idaho Springs, Colorado, Severson, R.C., and Stewart, K.C, eds, U.S. Geological Survey Circular 1097, p. 39-41.

Smith, K.S., and Huyck, H.L.O., 1999, An overview of the abundance, relative mobility, bioavailability, and human toxicity of metals: Chapter 2, in Plumlee, G.S., and Logsdeon, M.J., eds., The Environmental Geochemistry of Mineral Deposits, Part A: Processes, Techniques, and Health Issues, Reviews in Economic Geology, VOl. 6A: Littleton, Colorado, Society of Economic Geologists, Inc., P. 29-70.

Swayze, G.A., Clark, R.N., Pearson, R.M., and Livo, K.E., 1996, Mapping acid-generating minerals at the California Gulch Superfund Site in Leadville, Colorado using imaging spectroscopy, Summaries of the 6th Annual JPL Earth Science Workshop, March 4-8, 1996, p. 231-234.

Wait, J.R., 1982, Geo-electromagnetism: New York, Academic Press, 268 p.

Ward, S.H., [Ed.], 1990, Geotechnical and environmental geophysics: Tulsa, Soc. Expl. Geophys., [in three volumes] v. 1, 384 p., v. 2, 337 p., v. 3, 295 p.

Watson, K., Kruse, F. A., and Hummer-Miller, S., 1990, Thermal infrared exploration in the Carlin trend, northern Nevada: Geophysics, v. 55, n. 1, p. 70-79.

Watson, K., and Rowan, L.C., 1996, Recent applications of thermal infrared data for mineral exploration and environmental studies: Soc. of Exploration Geophysicists, 66th Annual Meeting, Denver, November 10-15, 1996, p. 1150-1152.

Winter, T. C., and Woo, M. -K., 1990, Hydrology of lakes and wetlands, in Wolman, R. G., and Riggs, H. C., eds., Surface water hydrology: Boulder, Colorado, Geological Society of America, The Geology of North Anerica, V. 0-1. 